\title{
ANALISIS PERAN KEPEMIMPINAN DALAM ORGANISASI BELAJAR
}

\author{
Oleh:Mutmainatul Mardiyah \\ Universitas MH. Thamrin
}

\begin{abstract}
Peran kepemimpinan pada sebuah institusi pendidikan menjadi sangat fundamental dalam menjadikan institusinya sebagai organisasi belajar. Untuk dapat mewujudkan organisasi belajar, maka seorang pemimpin pada sebuah institusi pendidikan dituntut untuk mampu melaksanakan peranan-peranannya secara terpadu. Dalam hal ini, penulis mengangkat peranan wirausaha atau entrepreneur dari seorang pemimpin dalam mewujudkan organisasi belajar. Melalui organisasi belajar, akan terwujud institusi pendidikan yang unggul sehingga mampu bersaing secara nasional maupun internasional. Penelitian ini bertujuan untuk mendeskripsikan lebih rinci tentang pelaksanaan peran kepemimpinan dalam organisasi belajar berdasar pada kajian literatur.
\end{abstract}

Kata Kunci: Kepemimpinan, Peran Kepemimpinan, Peran Wirausaha, Organisasi Belajar

\section{A. Pendahuluan}

Pada era global seperti sekarang, institusi pendidikan di Indonesia mengalami banyak perubahan, baik perubahan pada sistem, pengelolaan, serta lulusannya. Perubahan-perubahan ini tentu tidak terjadi secara tiba-tiba, melainkan terjadi karena adanya suatu proses yang panjang. Proses yang dimaksud adalah adanya interaksi di dalam dan di luar lingkungan institusi yang dilakukan oleh pemimpin, karyawan, dan para pembelajar.

Penggerak utama adanya proses interaksi di sebuah institusi pendidikan adalah seorang pemimpin. Peran dan fungsi kepemimpinan dari sebuah institusi pendidikan tentunya menjadi tolok ukur keberhasilan sebuah institusi. Ini berarti bahwa pemimpin sebuah intistusi pendidikan harus memiliki kemampuan dan kepekaan dalam menyesuaikan diri, serta dapat mempertimbangkan atau mengantisipasi segala kemungkinan yang akan terjadi pada kurun waktu tertentu.

Segala kemungkinan yang dimaksud merupakan hasil perwujudan kinerja seorang pimpinan institusi pendidikan dalam melakukan berbagai proses perubahan. Perubahan yang dimaksud adalah perubahan yang terkait dengan visi, misi, tujuan atau sasaran, prosedur, input, proses, atau output yang sesuai dengan tuntutan perkembangan. Perwujudan ini tidak terlepas dari peran dan fungsi kepemimpinan dalam sebuah organisasi belajar, serta fungsi dan kepemimpinannya dengan masyarakat. Oleh karenanya, untuk mencapai kondisi seperti ini dibutuhkan tekad yang mendalam dan menyeluruh dari seorang pemimpin, seluruh karyawan, juga para pembelajar yang berada dalam satu organisasi belajar.

Fenomena yang terjadi pada saat ini adalah masih adanya praktik-pratik yang tidak sesuai dengan teori-teori yang ada. Pemimpin datang ke kantor sekedar untuk memenuhi kewajiban bekerja atau untuk sekedar melaksanakan beban kerja struktural atau berdasar deskripsi kerja yang ditentukan oleh institusinya. Pelaksanaan tugas-tugasnya ini tidak dibarengi dengan beragamnya jenis peran dan fungsi yang ada pada dirinya. Peran dan fungsi tidak dilaksanakan secara terpadu, yaitu dilaksanakan secara terpisah antara satu peranan dengan peranan lainnya. Ketidak terpaduan antar peranan yang dijalankan akan membawa intitusi yang dipimpinnya dalam permasalahan yang besar. Permasalahan yang timbul tidak terjadi hanya berdampak pada internal institusi, tetapi juga berdampak pada ekternal institusi, yaitu masyarakat.

Institusi pendidikan sebagai wadah sebuah organisasi belajar berproses, tentu menjadi tantangan tersendiri bagi seorang pemimpinnya. Oleh sebab itu dibawah kepemimpinannya, organisasi belajar harus mampu mendesain dan menciptakan suatu organisasi yang bisa beradaptasi, berubah, berkembang, dan mengubah dirinya untuk menanggapi kebutuhan, harapan, dan aspirasi orang-orang baik di dalam, maupun di luar organisasi. Gambaran ini diartikan bahwa seorang pemimpin institusi pendidikan harus bekerja dan memberdayakan seluruh anggotanya untuk menyusun arah dan tujuan 
institusinya, dimana didalamnya juga menyangkut sistem nilai yang disepakati bersama dan tentu berorientasi pada kuantitas dan kualiltas .

Situasi ideal yang dijelaskan di atas belum dialami oleh penulis untuk saat ini, sehingga hal ini sangat menumbuhkan pemikiran dan pertanyaan tentang apa yang sesungguhnya terjadi pada institusi yang mengalami ketiadanya kemajuan atau perkembangan, bahkan yang terjadi adalah kemundurun, dalam ungkapan lain adalah institusinya tidak mengalami perkembangan atau perubahan yang lebih baik dan berkelanjutan. Berdasar kejadian ini, penulis menganalisa peran kepemimpinan dalam organisasi belajar, dengan mendeskripsikan peran-peran apa saja yang harus dijalankan secara terpadu oleh seorang pemimpin dalam organisasi belajar sehingga institusi pendidikan sebagai agen perubahan bisa terwujud, baik menjadi agen perubahan secara internal maupun hubungannya dengan masyarakat.

\section{B. Kajian Teori \\ Kepemimpinan}

Kepemimpinan diterjemahkan secara berbeda-beda oleh satu peneliti dengan peneliti yang lain. Sebagian peneliti mendefinisikan kepemimpinan sebagai pembahasan sifat-sifat, perilaku pribadi, pengaruh terhadap orang lain, pola-pola interaksi, hubungan kerjasama antarperan, kedudukan dari satu jabatan administratif, dan persepsi dari lain-lain tentang legitimasi pengaruh. Oleh karenanya, sebagai akibatnya, istilah kepemimpinan selalu merupakan konotasi yang tidak jelas dan menimbulkan makna yang ambigu (Yulk, 1994).

Dari adanya beberapa pengertian definisi kempemimpinan yang dianggapnya masih ambigu ini, Nahavandi (2000) mengambil beberapa definisi mengenai kepemimpinan menurut beberapa ahli. Ted dalam Dorothea (2002) menjelaskan bahwa kepemimpinan adalah aktivitas mempengaruhi orang lain agar bersedia bekerjasama untuk mencapai tujuan-tujuan yang mereka inginkan. Ahli lain yaitu Freeman dan Tailor dalam Dorothea (2002) menyatakan bahwa kepemimpinan adalah kemampuan untuk menciptakan kegiatan kelompok untuk mencapai tujuan organisasi dengan efektivitas maksimum dan kerjasama dari setiap individu. Definisi lain disampaikan oleh Janda dalam Dorothea (2002) bahwa kepemimpinan adalah tipe tertentu hubungan kekuasaan, yang ditandai oleh persepsi anggota kelompok bahwa anggota kelompok yang lain mempunyai hak untuk memberi perintah anggota lain untuk berpola perilaku tertentu, sesuai dengan aktivitasnya sebagai anggota kelompok. Sementara itu, Hemphill dan Coons dalam Dorothea (2002) mendefinisikan kepemimpinan sebagai perilaku individu, di mana ia mengarahkan aktivitas kelompok untuk mencapai tujuan bersama. Lebih lanjut kepemimpinan didefinisikan oleh Tannenbaum dan Massarik dalam Dorothea (2002) sebagai pengaruh interpersonal pada situasi tertentu dan bersifat memerintah atau memberi petunjuk melalui proses komunikasi untuk mencapai tujuan yang spesifik. Kepemimpinan juga diartikan sebagai interaksi antarindividu, dan bila seseorang memberikan informasi dengan cara tertentu, sehingga yang lain akan mengerti bahwa hasil kerjanya akan lebih baik bila berperilaku seperti yang diusulkan atau diinginkan, pendapat ini disampaikan oleh Jacob dalam Dorothea (2002). Definisi kepemimpinan dari ahli lainnya, yaitu Stogdill dalam Dorothea (2002), menyatakan bahwa kepemimpinan harus melibatkan orang-orang berstatus bawahan atau pengikut, melibatkan distribusi kekuasaan yang tidak merata di antara pemimpin dan anggota, serta menyangkut kemampuan memberikan perintah atau petunjuk kepada bawahan. Selain itu, kepemimpinan juga diartikan oleh Katz dan Kahn di dalam Dorothea (2002) sebagai penambahan yang berpengaruh atas kepatuhan yang mekanistik dengan pemerintah yang rutin. Hampir senada dengan definisi dari Ted, maka Koontz dan O'Donnel di dalam Dorothea (2002) mendefinisikan kepemimpinan sebagai usaha untuk mempengaruhi orang-orang dalam usaha mencapai tujuan. Ahli lain, yaitu Hosking di dalam Dorothea (2002) menyebut bahwa pemimpin adalah seorang yang membuat kontribusi efektif pada tatanan sosial, dan merupakan seseorang yang diharapkan dan dirasakan untuk dapat mengerjakannya. Kotter di dalam dorothea (2002) menyatakan bahwa kepemimpinan berhubungan dengan proses untuk menggerakkan orang-orang dengan petunjuk-petunjuk dan dengan tanpa paksaan. Pendapat yang senada juga disampaikan oleh Jacobs dan Jaques di dalam Dorothea (2002) bahwa kepemimpinan adalah proses pemberian petujunk yang berarti untuk mengumpulkan usaha dan mendorong kemauan berusaha serta untuk mencurahkan waktunya untuk mencapai tujuan. 


\section{Peran Kepemimpinan.}

Dalam pembelajaran organisasi, peran seorang pemimpin dipengaruhi oleh persepsi kebutuhan pembelajaran mereka dan bertindak berdasarkan pengikut yang mendukung pembelajaran (Dirkx, 1999). Ini diartikan oleh penulis bahwa pemimpin mempunyai tanggungjawab dan dituntut untuk berjalan di depan, serta mampu melayani orang lain, sekaligus berperan menjadi guru atau pelatih bagi orang lain, terutama bagi pegawai atau pengikutnya. Definisi senada tentang peran kepemimpinan disampaikan oleh (Ellinger et al. 1999) bahwa peran pemimpin meliputi kegiatan memegang tanggungjawab sebagai pelatih dan fasilitator pembelajaran dalam organisasi belajar. Hal ini penulis mengartikannya bahwa peran kepemimpinan terlihat dari bagaimana perilaku fasilitatif terhadap para pengikutnya dalam membantu pembelajaran dan pengembangan suatu organisasi yang dipimpinnya. Seorang pemimpin yang berperan sebagai pelatih dan pendukung membuat para karyawan atau anggota organisasi merasa lebih puas, karena mereka merasa mendapat perhatian dan bukan pengawasan atau diawasi.

Don Hellriegel, et al. (1982) mengungkapkan adanya tiga macam peranan seorang pemimpin yang dikaitkan dengan teori Harry Mintzberg, yaitu: interpersonal, informational, dan decisional roles, yang dijelaskan melalui bagan berikut:

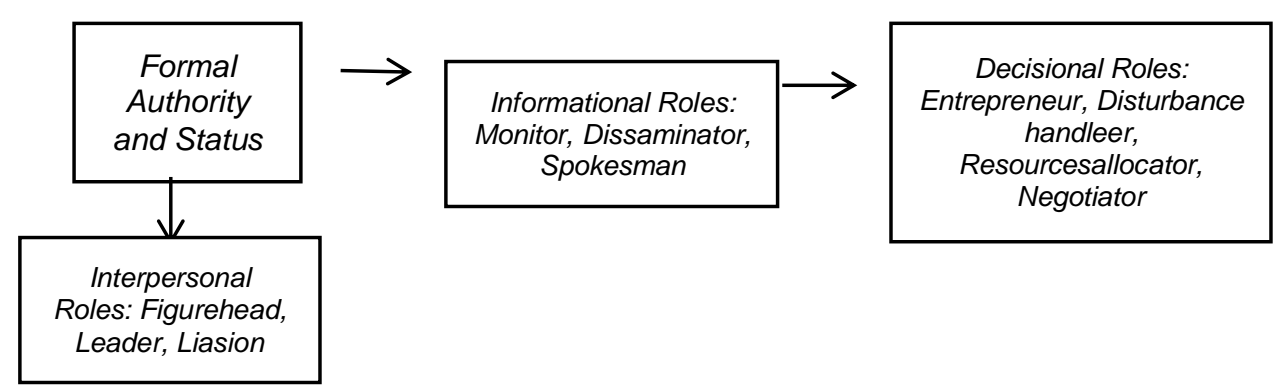

Secara singkat ketiga peran tersebut dijelaskan bahwa peranan hubungan antar perorangan (Interpersonal Roles) merupakan akibat otoritas formal dari seorang pemimpin yang meliputi figurehead, leadership, dan liasion. Selanjutnya oleh Don Hellriegel, et all (1982) menguraikan pengertian figurehead yang berarti lambang, maka seorang pemimpin memiliki peran sebagai lambang dari sebuah organisasi. Peran leadership dipandang sangat penting karena peranan ini merefleksikan tanggung jawab seorang pemimpin untuk menggerakkan dan mengontrol seluruh sumber daya yang ada pada organisasi yang dipimpinnya. Peran Liasion atau penghubung dimaknai bahwa seorang pemimpin adalah sebagai penghubung antara kepentingan organisasi dengan lingkungan di luar organisasi.

Pada peranan informasional, Don Hellriegel, et all (1982) menyebut bahwa seorang pemimpin berperan sebagai urat syaraf (nerve center), dan membaginya menjadi 3 (tiga) macam peran, yaitu sebagai monitor, disseminator, dan sebagai spokesman. Menurutnya, seorang pemimpin yang berperan sebagai monitor dituntut untuk selalu mengadakan pengamatan terhadap lingkungan, baik di dalam ataupun di luar lingkungan organisasi. Sedangkan pemimpin yang berperan sebagai disseminator mempunyai tanggung jawab untuk menyebarluaskan informasi kepada seluruh anggota, termasuk stake horlder yang berada di luar organisasi. Pemimpin yang berperan sebagai spokeman mempunyai tugas untuk menyebarkan informasi kepada lingkungan di luar organisasi yang dianggap perlu, yang dalam hal ini, pemimpin ini berperan sebagai wakil resmi dari sebuah organisasi.

Decisional role atau peranan pengambil keputusan adalah peranan yang dianggap paling penting dari kedua peranan sebelumnya, yaitu interpersonal dan informational roles. Dijelaskan oleh Don Hellriegel, et all (1982) bahwa terdapat 4 (empat) peranan seorang pemimpin sebagai pengambil keputusan, yaitu sebagai pengusaha (entrepreneur), yaitu pemimpin yang selalu berusaha untuk memperbaiki penampilan organisasinya baik secara fisik maupun kualitas; peran sebagai orang yang memperhatikan gangguan (disturbance-handler), yaitu seorang pemimpin mempunyai tanggung jawab dalam mengantisipasi segala akibat dari pengambilan keputusan olehnya; peran sebagai orang yang menyediakan segala sumber (a resource allocator), yaitu pemimpin yang mampu secara cermat 
dan teliti kepada siapa sumber-sumber daya yang ada harus dibagikan peruntukan dan kegunaannya; peran sebagai seorang negotiator, yaitu seorang pemimpin yang mampu untuk mengadakan pembicaraan dan bermusyawarah dengan pihak luar untuk kepentingan tujuan organisasinya.

\section{Organisasi Belajar}

Pedler, et al (1991) mendefinisikan organisasi belajar (learning organization) sebagai organisasi yang mendukung kegiatan atau proses pembelajaran bagi semua anggota yang secara terus menerus mengadakan perubahan. Ini bisa diartikan bahwa organisasi tersebut harus berkemampuan untuk mendesain dan menciptakan sebuah organisasi yang mampu beradaptasi, bertumbuh kembang, serta mengubah dirinya untuk merespon dan menjawab segala kebutuhan, harapan, dan aspirasi dari orangorang, baik orang-orang yang dari luar maupun dari dalam organisasi. Organisasi belajar juga diartikan sebagai hasil pembelajaran dan perilaku anggotanya, ini tentunya karena organisasi ini terdiri dari orang-orang yang berpengaruh pada pencapaian hasil. Diperjelas juga oleh Hong, 1999 bahwa di dalam organisasi belajar harus terdiri dari individu dan kelompok yang sanggup melakukan pembelajaran dan pemelajaran. Dengan melihat arti kata asalnya, pembelajaran merupakan proses atau cara menjadikan orang atau mahluk hidup belajar, sedangkan pemelajaran merupakan proses, cara, atau perbuatan mempelajari. Maka disimpulkan oleh Hong bahwa pembelajaran dalam organisasi bisa terjadi bila anggota organisasi secara individu menemukan ketidaksesuaian antara kondisi yang sesungguhnya dengan hasil yang diharapkan, dan mencoba mengoreksi kesalahan.

Terdapat 2 (dua) model organisasi, yaitu organisasi yang hanya mengutamakan efisiensi dan kinerja organisasi secara vertikal, dan organisasi yang mengutamakan efisiensi dan kinerja secara horisontal. Daft (1999) menjelaskan bahwa organisasi yang mempunyai struktur organisasi yang vertikal, dimana pimpinan dengan pelaksanaan tugas rutin, menggunakan budaya yang sangat tidak fleksibel dengan sistem yang sangat formal, model ini juga menggunakan strategi bersaing dalam meningkatkan kinerjanya. Sementara itu, organisasi belajar menggunakan struktur yang horisontal, di mana hubungan pimpinan dan pelaksana serta pelanggan terlihat dan terasa dekat, menerapkan pemberdayaan karyawan dan jaringan antarpribadi dengan dekat, menganut budaya yang adaptif dan juga proaktif, serta menggunakan strategi antarhubungan untuk meningkatkan kinerjanya. Perbedaan dari 2 (dua) model ini bisa terlihat dan terangkum pada gambar berikut ini:

\section{Dua Model Organisasi}

Kinerja Efisien (Keras, Model Rasional)

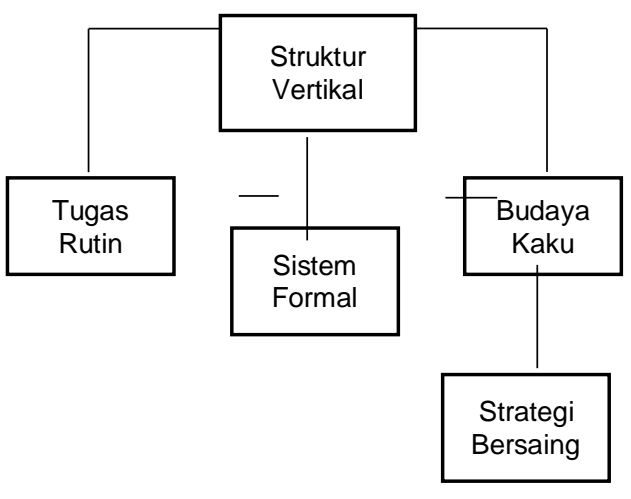

Organisasi Belajar (Lembut, Model Intuitif)

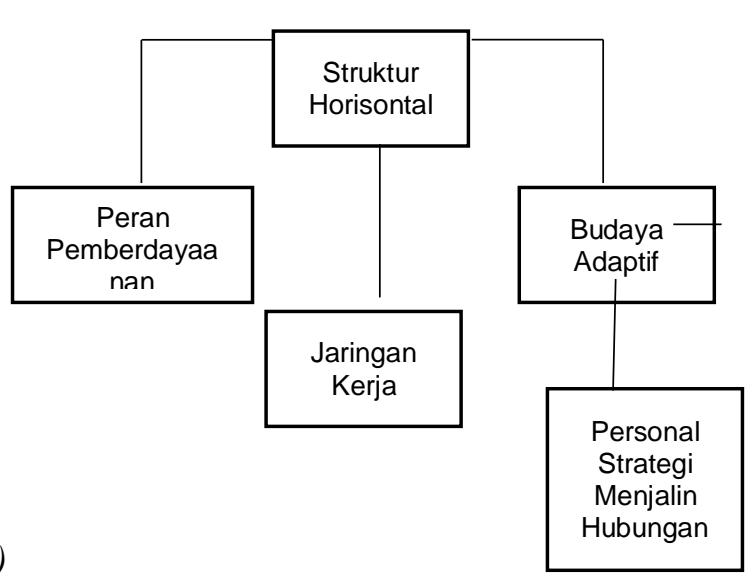

Cicmil dan Kekale (1997) menjelaskan bahwa dalam organisasi belajar, seluruh personil dalam organisasi atau perusahaan harus mau berubah, baik secara cepat maupun lambat. Kemampuan organisasi untuk beradaptasi bergantung pada kecepatan perubahan lingkungan yang merupakan faktor utama dalam mencapai kesuksesan dalam persaingan. Memposisikan diri sebagai organisasi belajar merupakan sebuah kendaraan yang mampu membawa suatu organisasi tetap unggul, bertahan, segar, cerdas,dan selalu baru. Lebih jauh dijelaskan oleh Cicmil dan Kekale (1997) bahwa pembelajaran individu dan organisasi menjadi inti pengelolaan yang proaktif untuk memberikan yang 
terbaik bagi pelanggan dengan pencapaian tujuan organisasi secara menyeluruh bersama karyawan, pelanggan, dan pemasok.

Pendapat senada oleh (Huysman, 2000) bahwa untuk mewujudkan organisasi belajar, dibutuhkan pendekatan yang berwujud pembelajaran dalam organisasi. Pembelajaran dalam organisasi (organizational learning) merupakan aspek dasar dalam evolusi atau perkembangan organisasi dan dalam operasi organisasi, sehingga menghasilkan perbaikan di dalam organisasi. Menurut Senge (1990), organisasi yang dapat menangani dan siap menghadapi tantangan dikatakan sebagai organisasi belajar.

\section{Metodologi}

Penelitian ini merupakan sebuah conceptual paper yang terkait dengan pelaksanaan peran kepemimpinan dalam organisasi belajar, yaitu melalui data-data yang ditemukan dan informasi yang diperoleh dari data sekunder, baik yang berasal dari textbook ataupun dari publikasi ilmiah. Tulisan ini sangat diharapkan dapat memberikan manfaat dan menjadi referensi bagi setiap pemimpin organisasi, khususnya institusi pendidikan dalam menciptakan organisasi belajar sehingga tujuan organisasi yang dipimpinnya bisa berkembang dan tercapai. Pada penelitian ini, yang dimaksud dengan organisasi adalah institusi pendidikan yang mencakup sekolah, perguruan tinggi, sekolah, ataupun lembaga kursus.

\section{Analisis dan Pembahasan}

Berdasar pada beberapa pengertian dan definisi kepemimpinan yang dinyatakan dalam kajian teori, penulis menyimpulkan bahwa kepemimpinan merupakan serangkaian aktifitas atas kegiatan mengelola melalui mempengaruhi orang lain untuk berperilaku sesuai peran masing-masing dan bekerja sama dalam situasi ruang dan waktu tertentu dalam usaha mencapai tujuan yang telah direncanakan bersama. Terkait dengan kesimpulan ini, tentunya seorang pemimpin institusi pendidikan mempunyai tanggung jawab atas seluruh rangkaian kegiatan yang ada dalam suatu organisasi, yaitu perguruan tinggi, sekolah atau lembaga kursus. Tanggung jawab ini bisa dikembangkan fungsinya menjadi sebuah peranan dari seorang pemimpin, sehingga bisa dikatakan bahwa kegagalan dan keberhasilan suatu organisasi atau institusi pendidikan sangat bergantung pada peran dan dukungan pemimpinnya.

Untuk menganalisa bagaimana pelaksanaan peranan-peranan pemimpin yang telah dijelaskan pada kajian teori, yaitu peran interpersonal, informational, dan decisional atau peran pengambil keputusan, penulis mencermatinya melalui segala yang timbul atau terjadi pada proses pencapaian dari suatu institusi pendidikan. Oleh karenanya dibutuhkan pelaksanaan peran yang menyeluruh atau terpadu, dan tidak dengan secara partial atau sebagian peranan saja. Yang paling menarik perhatian penulis pada 3 (tiga) jenis peranan ini adalah dinyatakan bahwa pengambilan keputusan merupakan peran yang paling penting dari 2 (dua) peran lainnya. Peran pengambilan keputusan (decisional role) dibagi lagi oleh Don Hellriegel, et all (1982) menjadi 4 (empat) peranan yang salah satunya adalah peranan wirausaha (entrepreneur). Pada penelitian ini penulis membatasi hanya menganalisa bagaimana dan apa yang seharusnya seorang pemimpin institusi pendidikan sebagai pengambil keputusan dalam menjalankan perannya sebagai seorang wirausaha (entrepreneur). Tentunya seorang pemimpin institusi pendidikan harus benar-benar memposisikan dirinya sebagai seorang entrepreneur. Ini berarti bahwa seorang pemimpin institusi pendidikan yang menjalankan peranan entrepreneur harus memiliki beberapa kompetensi yang meliputi kompetensi karakter, kompetensi komunikasi, kompetensi kreativitas dan inovasi, kompetensi menjual produk/jasa, kompetensi manajemen usaha. Mengacu pada kelima kompentensi tersebut, penulis memposisikan kemampuan karakter di tempat tertinggi dan merupakan kompetensi yang paling utama yang harus dimiliki. Ciriciri seorang pemimpin yang berkarakter harus berani bermimpi, artinya pemimpin tersebut harus selalu berusaha untuk memperbaiki eksistensi institusi yang dipimpinnya melalui berbagai macam ide dan gagasan, seperti menciptakan visi, misi, dan tujuan. Seorang pemimpin yang berkarakter juga harus cerdas (smart), maksudnya adalah bahwa visi, misi, dan tujuan yang diciptakannya harus spesifik (specific), bisa diukur (measureable), bisa dicapai (achievable), masuk akal (realistic), dan memiliki garis waktu yang jelas (time bond). Ciri lain seorang pemimpin yang berkarakter adalah memotivasi diri sendiri, mampu untuk menyelesaikan masalah, menemukan peluang, mengembangkan gagasan usaha, dan ketegasan dalam aspek produksi. Yang dimaksud aspek 
produksi pada sebuah institusi pendidikan adalah aspek-aspek termasuk kurikulum dan silabus, serta bagaimana proses belajar mengajar dalam kurun waktu tertentu yaitu per-kuartal atau per-semester.

Dengan cirif-ciri yang ada pada kompentensi karakter yang dimiliki oleh seorang pemimpin institusi pendidikan, tentunya dengan sendirinya terlahir kompetensi komunikasi, yang mana kompetensi ini merupakan penggerak untuk melahirkan kompetensi-kompetensi lainnya, yaitu kreatifitas \& inovasi, kompetensi menjual produk atau jasa, serta kompetensi menajemen usaha.

Selanjutnya penulis melakukan analisa tentang bagaimana berlangsungnya proses organisasi belajar dalam sebuah istitusi pendidikan. Seperti yang telah dijelaskan oleh Daft bahwa ciri-ciri organisasi yang mengalami proses organisasi belajar adalah organisasi yang mempunyai struktur yang horisontal, menerapkan pemberdayaan karyawan dan jaringan kerja, menganut budaya yang adaptif dan juga proaktif, serta menggunakan strategi antarhubungan.

Dari penjelasan tersebut, penulis mencermati bahwa sebuah institusi pendidikan dalam mewujudkan organisasi belajar (learning organization) tersebut membutuhkan waktu yang panjang dan melalui pendekatan pembelajaran. Yang dimaksud pembelajaran di sini adalah pembelajaran organisasi atau organizational learning, yang bisa diartikan sebagai faktor mendasar atau fundamental dalam perkembangan sebuah institusi pendidikan, dan tentu pembelajaran organisasi ini tidak terbatasi oleh ruang dan waktu.

Oleh karenanya, uraian ini bisa ditarik suatu ukuran atau dimensi mengapa atau atas alasan apa sebuah institusi pendidikan membutuhkan suatu proses organisasi belajar. Alasan pertama adalah setiap institusi pendidikan mempunyai visi, misi, dan tujuan yang harus berlangsung dengan baik atau lebih baik, dan minimal sama dengan lingkungan, karena jika tidak demikian, institusi pendidikan tersebut akan mati. Alasan kedua adalah untuk pencapaian keunggulan institusi pendidikan itu sendiri. Gejala atau fenomena yang bisa peneliti cermati saat ini adalah bahwa dengan melalui keunggulannya, sebuah institusi pendidikan dapat melangsungkan kehidupannya, baik dalam lingkungan maupun dengan pesaingnya. Dengan terwujudnya organisasi belajar pada sebuah institusi pendidikan berarti institusi ini mampu memberikan iklim yang mendukung seluruh anggotanya yang meliputi karyawan, mahasiswa/siswa, orangtua mahasiswa/siswa dan juga pemegang kepentingan atau stakeholders yang berada di luar institusi, seperti para users atau pengguna para lulusannya dalam mengadakan perbaikan secara berkelanjutan.

\section{E. Kesimpulan dan Saran}

Setiap institusi pendidikan menginginkan terjadinya organisasi belajar dalam proses mewujudkan visi, misi, dan tujuan organisasinya untuk menjadi lebih baik. Di Indonesia saat ini, dimana semua institusi pendidikan dituntut untuk melaksanakan kurikulum yang mengacu pada KKNI (Kerangka Kualifikasi Nasional Indonesia), maka menjadi paling sesuai dan pas untuk melakukan pembelajaran dan pemelajaran di segala aspek kehidupan berbangsa yang meliputi aspek ekonomi, politik, ekonomi, hukum, dan pendidikan. Banyak pihak yang mengatakan bahwa aspek pendidikan merupakan aspek yang terpenting dalam pelaksanaan KKNI. Oleh karenanya peran kepemimpinan dalam mewujudkan organisasi belajar harus benar-benar dilaksanakan dengan baik agar terwujud institusi pendidikan yang unggul sehingga mampu bersaing secara nasional maupun internasional. 


\section{Daftar Pustaka}

Cicmil, S. Dan Kekale, T. Implementations of Organizational and Individual Learning for Effective Change Management in Education: An Exploratory Study of Management Practice in Elementary School in England and Findland. Journal of Workplace Learning, 9 (5), 169-176. Diakses dari www.emerald-library.com tanggal 16 Agustus 2017

Daft, R.L. Leadership: Theory and Practice. Tokyo: Harcourt Brace College Publishers. 1999 Dirkx, J.M. Invited Reaction: Managers as Facilitators of Learning in Learning Organization. Human Resource Development Quarterly, 10 (2), 105-125. Dari CD-ROM. 1999

Dorothea, W. A. Manajemen Kualitas, edisi pertama. Jakarta: Penerbit Galia Indonesia. 2002 Ellinger, A.D., Watkins, K.E., dan Bostrom, R.H. Managers as Facilitators of Learning in Learning Organization. Human Resource Development Quarterly, 10 (2), 127-134. Dari CD-ROM. 1999 Hellriegel, Don. Management, 3rd Edition, Eddison-Wesley Publishing Company, Inc., Philippiness. 1982

Hong, J. Structuring for Organizational Learning. The Learning Organization Journal, 6 (4), 173-185. Diakses dari www.emerald-library.com tanggal 16 Agustus 2017

Huysman, M. An Organizational Learning Approach to The Learning Organization. European Journal of Work and Organizational Psychology, 9 (2), 133-145. Diakses dari www.tandf.co.uk/journals/pp/13594x.html tanggal 22 Agustus 2017

Navandi, A. The art and Science of Leadership, 2nd edition. New Jersey: Prentice-Hall International, Inc. 2000

Pedler, M., Burgoyne, J., dan Boydell, T. The Learning Company: A Strategy for Sustainable Development. London: McGraw-Hill Book Company. 1991

Yulk, G. Leaderships in Organization, 3rd edition. New Jersey: Prentice-Hall International, Inc. 1994 